Etnográfica

Revista do Centro em Rede de Investigação em

Antropologia

vol. $25(2) \mid 2021$

Vol. 25 (2)

\title{
The sorrow and the hope of a dancer: remembering Still/Here twenty-five years after the première of Bill T. Jones' dance piece
}

O sofrimento e a esperança de um bailarino: recordar Still/Here, de Bill T. Jones, vinte e cinco anos após a sua estreia

\section{Maria José Fazenda}

\section{(2) OpenEdition}

\section{Journals}

Electronic version

URL: https://journals.openedition.org/etnografica/10455

DOI: 10.4000/etnografica. 10455

ISSN: 2182-2891

\section{Publisher}

Centro em Rede de Investigação em Antropologia

Printed version

Number of pages: 493-511

ISSN: 0873-6561

\section{Electronic reference}

Maria José Fazenda, "The sorrow and the hope of a dancer: remembering Still/Here twenty-five years after the première of Bill T. Jones' dance piece", Etnográfica [Online], vol. 25 (2) | 2021, Online since 29 July 2021, connection on 19 January 2022. URL: http://journals.openedition.org/etnografica/10455; DOI: https://doi.org/10.4000/etnografica. 10455

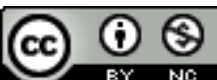

Etnográfica is licensed under a Creative Commons Attribution-NonCommercial 4.0 International License. 


\section{The sorrow and the hope of a dancer: Remembering Still/Here twenty-five years after the première of Bill T. Jones' dance piece}

\section{Maria José Fazenda}

North American choreographer, Bill T. Jones started his activity as a professional dancer in the 1970s. Jones practices and thinks about art and creativity explicitly in its direct relationship not only with his own but larger communities life experience. Still/Here (1994) is a piece that, precisely, marks a milestone in the context of society and the art of the end of last century, particularly by addressing a relevant topic that has informed the experience of many people at that time in Euro-American society arising from HIV and AIDS crisis. In this paper, starting from the premise that reflexivity (Turner 1987) is a characteristic of theatrical dance, focusing on the modes of representation of emotional experiences on Jones's work, and relating it to pieces created before and after Still/Here - namely, D-Man in the Waters, Achilles Loved Patroclus and Ursonate - I intend to argue that these emotional expressions have a motivation that, beyond the psychobiological explanations (Lutz and White 1986), is only understandable if we consider the position (Rosaldo 1984) from which Jones lives his experiences and constructs his vision of the world, and a meaning that is only perceived in the light of the "biographical context" (Gell 1998) of the choreographer.

KEYWORDS: theatrical dance, Euro-American dance tradition, reflexivity, emotional expression, representation.

O sofrimento e a esperança de um bailarino: recordar Still/Here, de Bill T. Jones, vinte e cinco anos após a sua estreia - Coreógrafo norte-americano, Bill T. Jones iniciou a sua atividade como bailarino profissional na década de 1970. Jones pratica e reflete sobre a arte e a criatividade estabelecendo uma relação direta com a sua própria experiência de vida e a sociedade em que vive. Still/Here (1994) é uma peça que, precisamente, representa um marco no contexto da sociedade e da arte do final do século passado, nomeadamente por abordar um tema relevante que afetou a experiência de muitas pessoas na sociedade euro-americana naquela época decorrente da crise do HIV/SIDA. Neste texto, partindo da premissa de que a reflexividade (Turner 1987) é uma característica da dança teatral, atendendo aos modos de representação das experiências emocionais no trabalho de Jones, e concentrando-me em peças criadas antes e depois de Still/Here - a saber, D-Man in the Waters, Achilles Loved Patroclus e Ursonate -, argumentarei que a expressão emocional, para além das explicações psicobiológicas (Lutz e White 1986), tem uma motivação que só será compreensível se considerarmos a posição (Rosaldo 1984) a partir da qual Jones vive as suas experiências e constrói a sua visão de mundo e um significado que só é percebido à luz do "contexto biográfico" (Gell 1998) do coreógrafo. 
PALAVRAS-CHAVE: dança teatral, tradição euro-americana, reflexividade, expressão emocional, representação.

FAZENDA, Maria José (mjfazenda@esd.ipl.pt) - Escola Superior de Dança, Instituto Politécnico de Lisboa; Centro em Rede de Investigação em Antropologia (CRIA-IUL), Portugal.

\section{INTRODUCTION:}

\section{BEING A CHOREOGRAPHER IN THE EURO-AMERICAN CONTEXT}

“Pendant de nombreuses années, j’ai considéré les émotions comme une arme supposée me rendre fort. [...] Je ne suis pas maitre de mes émotions. C'est d'ailleurs l'une de mes préoccupations actuelles. Du coup, j'ai peur de faire le moindre écart, et je deviens moins disponible, car je ne suis pas sûr de mes réactions." (Jones 2013: 29)

North American dancer and choreographer Bill T. Jones brings onto the dance stage both his visions of the world and representations of his own experiences - experiences that come with age, gender, race, illness, emotions, beliefs and values. ${ }^{1}$ Reflexivity is a characteristic of theatrical dance. As Turner defines it, "reflexivity is a condition in which a socio-cultural group, or its most perceptive members, acting representatively, turn, bend or reflect back upon themselves [...]" (1987: 24). Jones is a choreographer, a profession that in the Euro-American context is recognized as being creative and emotional, and, as I will try to underline, also reflexive. Dancing is for Bill T. Jones the expression of emotions, of conflicts, of doubts, of a critical overview of the world, but it is also through dance that the choreographer can better understand his own experiences. The way he verbalizes that relationship strengthens the intentionally reflexive dimension of his dances.

Between 1992 and 2005, I accompanied Bill T. Jones' work and was present at his performances in several towns and theatres in Europe, which gave me the opportunity to interview the choreographer in several moments. I could

I This text includes excerpts from a previous work dedicated to Bill T. Jones, published in Portuguese (Fazenda 2007), specifically segments from interviews with the choreographer and passages from the descriptions of his dance pieces. I am deeply grateful to Bill T. Jones for his generosity, confidence and availability to talk to me. Without him it would have been impossible to write this essay. The title of this essay is inspired by the title of Edward Schieffelin's book The Sorrow of the Lonely and the Burning of the Dancers (1976), an anthropological study that focuses on "Gisaro", a ceremony performed by the Kaluli people of Papua New Guinea, where other aspects of Kaluli life and experience are made visible. 
do it first as a collaborator in the Portuguese newspaper Público (between 1992 and 2001). Later my aim was to elaborate one of the parts of my $\mathrm{PhD}$ thesis, which has since been published (Fazenda 2007). Building on that work, I propose to remember Still/Here 25 years after its premiere in 1994. Still/Here is a piece that marks a milestone in the context of society and the art of the end of last century, particularly by addressing a relevant topic that has informed the experience of many people at that time in Euro-American society - the experience of fear, loss and segregation, but also of hope and solidarity, brought on by HIV and AIDS crisis. In this paper, focusing now on the modes of representation of emotional experiences on Jones' work, and relating it to pieces created before and after Still/Here - namely, D-Man in the Waters, Achilles Loved Patroclus and Ursonate -, I intend to argue that these have a motivation that is only understandable if we consider the position from which he lives his experiences and constructs his vision of the world, and a meaning that is only perceived in the light of the "'biographical' context" (Gell 1998: 11) of the choreographer, by which I mean, following the anthropologist that defined the premises of an anthropology of the art, relationships established in a certain phase of the "life cycle" of the agent.

In this paper, the theoretical orientation is interpretative, based on examination of the dance as "a representational practice that explores rigorously strategies for developing bodily signification [...]" (Foster 1996: xiii), and on the assumption that theatrical dance is a continent of reflexivity, of interpretations that people make about their own lives and experiences, or, in the words of Geertz, "a story they tell themselves about themselves" (1973: 448). This essay is then built on the premise that theatrical dance is a universe of meanings by which people represent their worldviews and simultaneously materialize a form of experience.

And when we refer to experience, what do we refer to? We should consider at least two experiential spheres.

One is the experience of incorporating and sensing the movement, an experience that involves cultural meanings for those who dance and those who watch dancing. Bill T. Jones started his activity as a professional dancer in the 1970s with his collaborator and partner Arnie Zane. In the world of contemporary choreographic art in the Euro-American context, from the 1970s, there is a set of knowledge and practices of dances - conventions that define the perimeters of an art world (Becker 1982) - that can be adopted by choreographers in an individual, unique, way. In this context, Bill T. Jones, as he is developing his activity, introduces his own way of working materials of movement, composing dances from the plurality of various movement styles he learns and incorporates - Jones studied classical dance, modern dance, contact improvisation, African dance, improvising techniques; he practiced yoga, and was interested in Indian dance. 
What is unique in the style of Jones is, ${ }^{2}$ on the one hand, the expressive use of several dance materials coming from different dancing conventions, and, on the other hand, the way these various elements are linked, unexpectedly, to each other. That is, in a duet, spontaneous and free flow of movement, and weight transfers from one body to another, in the style of contact improvisation, ${ }^{3}$ can be interrupted by the creation of an elongated body shape, with legs and feet outstretched, characteristic of classical dance (ballet).$^{4}$ Likewise, the balance of an arabesque (body supported on one leg, with the elongated torso, while the other leg is extended and raised) can be broken by the curving and the twisting of the torso, within the style of Cunningham technique. ${ }^{5}$ Yet, elsewhere, the classicism of the vertical patterns can be shaken by the percussion of the feet, dynamic actions manifested in some Western African dances, ${ }^{6}$ or broken by the use of pedestrian movements.

The second experiential level we should consider is the individual experience of the artist, the person, an experience that comes from the age, sex and gender, disease, emotions, beliefs of the person socially (the area of interpersonal relationships) and culturally (realm of ideas, values and symbols) situated.

In this paper, I propose to interpret the meanings produced in a dance through the articulation of the movement signification with the specific con-

2 I use the concept of style, such as Susan Foster defines it, that is, "the way the dance achieves an individual identity in the world and in its genre" (1986: 59). One style of motion refers to an arrangement of visual and kinesthetic distinctive properties. These properties result, following Foster, from the articulation of the three crucial factors involved in any movement: the qualitative aspects of the movement (the combination of time, space, weight and flow), the body parts involved in movement, and the way the body uses the space.

3 The name contact improvisation, whose invention is attributed to the North American dancer Steve Paxton, in the 1970s (Novack 1990), describes exactly what happens physically and visually: contact between two performers, from which it is created a continuous improvised movement. Contact improvisation is not based on specific movement vocabulary, but rather in the development of sensory skills founded on certain principles that govern the interaction between the two bodies - playing, sharing weight from one body to the other, preserving a fluid movement and responding continuously to new situations.

4 The ballet is a style of movement and a kind of performance whose origins date back to the $17^{\text {th }}$ century in Europe (especially France and Italy) and since then has developed into several subgenres and been used in different performances and contexts, and with several purposes. Its language is based on a nomenclature of steps and movements, virtuously executed, designated in French, and known by all who practice it. Aesthetically, the elongated lines, the vertical projection of movements in space and the geometric patterns are particularly appreciated.

5 The North American dancer and choreographer Merce Cunningham (1919-2009) has invented a dance technique in which the movements of the torso (curves arches, twists) are highly valued and often articulated with fast and intricate movements of the legs.

6 The percussive movement of the feet is one of the elements, according to Thompson (1974), which identifies the style of dance in West Africa. Novack (1993), referring to the "traditional Ghanaian dance", also distinguishes the percussive movements and accents executed by the dancers. 
text in which the choreographer develops his work and how he sees himself as a person and as an artist.

\section{THE EMOTIONAL DANCER AND THE EXPRESSION IN DANCE}

Before founding the Bill T. Jones/Arnie Zane Dance Company with his partner, Arnie Zane, in 1982, Bill T. Jones had created and interpreted in a confrontational way some particular solos that, according to written sources and the opinion of Jones himself, expressed a rage that frequently erupted into verbal and gestural hostility directed at the audience.

Regarding one of the sections of Everybody Works / All Beats Count (1975), Jones recalls in his autobiography that when he presented the solo in an audition for the Clark Center Dance Festival, he suddenly raised his fist and made an obscene gesture coupled with a blasphemy directed at the audience. The jury selected the dance provided that he removed the offensive material, which he did. However, in another performance of the same dance, in 1977, Jones alternated between seductive moves whose aim was to attract the sympathy of the public and making faces (Jones and Gillespie 1995: 136-137). In 1981, in an improvised solo performed for the American Dance Festival, the choreographer verbally attacked the audience with the following contradictory statements: "I love women. I hate women. I love white people. I hate white people. Why didn't you leave us in Africa? I'm so thankful for the opportunity to be here" (ibid.: 165).

Gay Morris (2001) analyzed Bill T. Jones dancing solos between the end of the 1970s and the beginning of the 1980s. These solos, which were emotionally explosive and aggressive, shocked the audience. As Morris remarks, the audience at that time was mostly white. Morris' theory is that Jones confronted three conceptions of the dominating ideology that "emasculated" simultaneously the dancer, the black male and the gay man.

"The first is the perception in a dominant white society that a black man is less than a man because he is not fully accorded a white man's power. The second is the notion that a male dancer is less than a man because he occupies the feminized space of the concert stage, and the third the belief that a gay man is less than a man because he does not sexually reproduce." (Morris 2001: 244)

Jones responded to this demeaning with dances in which he simply turned his back on these conceptions, or explored them and then threw them at the audience, or reconfirmed racial and gender expectations. Any of these attitudes followed, according to Morris, from a strategy aimed at having "control of perceptions of his identity and to empower the 'weak' masculinities that his 
race, profession and sexual orientation would customarily have forced upon him" (ibid.: 244).

By analyzing and interpreting the reason for the aggressivity and emotional explosion of Jones' first solos, Morris considers the position of the male Afro-American choreographer in a certain social setting. This is the contextualization that allows the author to give meaning to that emotional expression well beyond a possible simplistic explanation based on hypothetical cathartic purposes of dancing.

In 1988, the dancer, referring to these solos and trying to understand why they had this emotionally aggressive feature, admitted it was a strategy to control the way he thought the audience perceived him:

"Because while I loved the stage area as a place of transformation, it always angered me. I love to go in a room and move, but when there's an audience - I think it must be a feeling women have... There is something about the spectators saying, in effect, 'Perform for us. Show us your body.' So it made me extremely aggressive, and maybe that was my desire to impose masculine control - I also assume it was racial." (Jones et al. 1988: 89)

Bill $\mathrm{T}$. Jones locates the meaning of the emotional experience and expression far beyond the boundaries of his dancing body, in which emotion erupts and grows. The choreographer integrates the emotion into a communication system - the performance itself - with politically and social reflexive purposes, in a particular political and sociocultural context that informs the way he sees himself and how he perceives others to see him. As Lutz argues:

"Although we may experience emotion as something that rises and falls within the boundaries of our bodies, the decidedly social origins of our understandings of the self, the other, the world, and experience draw our attention to the interpersonal processes by which something called emotion or some things like joy, anger, or fear come to be ascribed to and experienced by us. [...] Emotional meaning is then a social rather than an individual achievement — an emergent product of social life." (Lutz 1998: 5)

In an anthropological analysis and interpretation of dancing, neglecting the experiences and the subjects' emotional expressions would be as artificial as separating body from mind, or movement from meaning. However, the frequent direct association between body movement and emotion has prevented dancing from being seen as a form of culture. Relegated to the sphere of the natural and understood as an activity that conveys a universal language, dancing is frequently deprived of its symbolic dimension and reduced to the most primitive emotional impulse. The commonsense idea according to which 
dancing is essentially a universal language separated from culture is far from being overcome. In Western society and culture there are at least three widespread theories on the person and on relationship between the human body and movement historically inscribed which are still contributing to the reinforcement of those ideas.

First, the theories of self-expression, as defended by Herbert Spencer in the $19^{\text {th }}$ century, which explained the origin of dancing by the existence of a natural and innate causal relation between emotions and muscular excitation: "Dancing $[\ldots]$ is a rhythmical action natural to elevated emotion" (Spencer 1968 [1857]: 223). The doctrine of self-expression, based on the idea that the movement of the body results from the feeling-acting proposed by Spencer, is extended in the anthropological literature of the $19^{\text {th }}$ century (Tylor 1881 ; Frazer 1890) and was disseminated in the $20^{\text {th }}$ century by the universal histories of dance (Sachs 1937; Haskell 1960; Nettl 1966; Sorrell 1967), thus contributing to spread both the assumptions of the emotional content of dancing, and the evolutionist assumptions according to which the emotional nature of dancing would correspond to a primordial and primitive function.

Secondly, the Darwinist thesis that argues emotions and their physical expressions are universal because they are the product of our own evolution and therefore part of our biological heritage (Darwin 1872).

Thirdly, the development of the theories that, under influence of the new perspectives introduced by Freud, have incorporated from the 1930s onwards a vocabulary and certain explanations with a psychological content in order to explain the characteristics and functions of dance. The anthropological theories (Benedict 1934), the theories of the history of dance (Sachs 1937), and the discourses of the artists themselves emphasized the cathartic purpose of dancing, neglecting the reasons that would justify the formal differences recorded between dances.

In order to be able to reintegrate emotional experience as a factor that constitutes the person and conducts the dancers actions and movements we need, as Lutz and White suggest, to go "beyond its original psychobiological framework to include concern with emotion's social relational, communicative, and cultural aspects" (1986: 405).

In line with the proposal of Renato Rosaldo, who in turn retrieves the notion of positioned subject that runs through the work of Pierre Bourdieu, I argue that in order to understand the scope of the emotional experiences that Bill $\mathrm{T}$. Jones expresses on stage it is fundamental to consider the position from which the choreographer lives his experiences and constructs his vision of the world. In the words of Rosaldo: "[...] the concept of position refers to a structural location from which one has a particular angle of vision. [...] Position can also refer to how one's lived experience both enables and inhibits particular kinds of insight" (1984: 192-193). 
We would add that in the case of theatrical dance - one kind of performance that is characterized by the separation between those who dance and those who watch, and the construction of a frame separated from the other world events but to which it refers reflexively (Fazenda 2007) - it is also important to consider the artistic and cultural conventions that structure the modes of expression of emotion and their meanings.

In the context of the Euro-American theatrical dance tradition, emotions may be considered an inherent aspect of artistic practice at least on three levels: emotional experience as a factor that motivates the creative act; emotional experience as it is reconstituted or turned into fiction (when it is about a nonlived, an imagined experience) through an idea of movement and a concept of dance composition; and the emotion aroused during the act of performance itself, which expression can affect, either reinforcing either contradicting, the previous representations of emotional experience.

The philosopher Susanne K. Langer argues that the emotion experienced in response to actual events is different from the emotion formulated symbolically in art, and that the symbolization is not a mere transposition or projection but implies a transformation, an abstraction:

"Every symbolic projection is a transformation. There are projections which are merely transpositions, such as the projection of a picture from a slide to a screen, but they are not symbolic. The function of a symbol is not only to convey a form, but in the first place to abstract it; and this requires transformation, because it is the sameness of logical structure in experientially different loci that makes it." (Langer 1988: 47)

The emotional experience in dance is represented through the mechanisms of dance composition and the dancing conventions (techniques and styles of movement, presence of the performers and interaction between them). ${ }^{7}$ In this sense we can say that in dance the presence of the body and its movements are the main materials of what Hogan (201 1: 19), referring to the representation of emotion in literature, termed as "depictive representation" of emotional experience.

Historically, in dance, it is in the $18^{\text {th }}$ century, particularly with Jean Georges Noverre (1760), that the expression of emotion acquires special significance. According to this maittre de ballet, ${ }^{8}$ dance had degenerated into excessive

7 In dancing, composition is the act of elaborating, working with, and arrange movement in time and space, and with a certain energy, and may involve several operations: amplification, reduction, repetition, variation, development, acceleration, deceleration, cutting, editing, addition, subtraction, etc.

8 At that time, the term maître de ballet denoted simultaneously the composer of ballets and the dance teacher - the belle danse or academic dance teacher, which technical form and style is, nowadays, designated classical dance (or ballet). 
technical virtuosity. Noverre defends the necessity of a renovation that transformed ballet into an imitative art, capable of representing the human passions through gestures, pantomime and expressivity. The pantomime will be developed over the $19^{\text {th }}$ century ballets, becoming a coded sign language, able to translate the actions, motivations, emotions and feelings of the characters represented and danced.

Later on, in the mid- $19^{\text {th }}$ century, François Delsarte develops a complex body language system, based, on one of its aspects, in the correspondence between emotions and body movements (see Porte 1992). Under major influence of his thought, but also in the wake of the developments of the German Ausdruckstanz (dance of expression) and the psychoanalysis of Freud and Jung, North American modern dance, in the first half of the $20^{\text {th }}$ century, puts its focus on the artistic expressiveness of an emotional interiority (Murphy 2007: 53-57). The influential North American modern dancer and choreographer Martha Graham stated: "Movement never lies. It is a barometer telling the state of the soul's weather to all who can read it" (Graham 1991: 4). Later on, at the end of the 1970s, under the influence of German choreographer Pina Bausch, "a renewed interest in meaning, emotion and narrative began to surface" in North American dance, as the dance historian Deborah Jowitt (1994 [1983]: 176) underlines.

It is in the context of a dance whose aesthetic principles are based on the expressiveness of movement and emotional expression that Bill T. Jones begins his work as a dancer, although he had practiced and incorporated other movements, dance techniques and styles based on principles opposed to the conception of movement as the expression of an emotional interiority, such as Cunningham technique and contact improvisation. As mentioned above, it is with the integration of these various materials that he finds his style, unique.

The idea I intend to emphasize is that integrating emotional experience in the analysis and interpretation of dancing within the Euro-American theatrical dance tradition - whether regarding emotional motivation, emotions reconstituted or turned into fiction through a process of symbolization - is extremely important. The role of emotion in dance cannot be neglected, especially when emotions are factors valued by choreographers and dancers as driving forces for the artistic practice, such as is the case of Bill T. Jones.

\section{THE SORROW AND THE HOPE OF A DANCER}

In order to understand the meanings that a work conveys on an emotional level it is also fundamental that emotions are perceived in the context of relationships and social interactions that directly affect and transform the life of the agent; relationships that are, as Gell puts it, "biographically consequential ones" (1998: 11). Bill T. Jones has helped us clarify this association between 
emotion and meaning. Once I questioned him about the way he transmitted a dance created in a given emotional context to other dancers that were not aware of the circumstances in which the work was originally produced. I referred especially to D-Man in the Waters, created in 1989 in a dramatic moment in the life of both the choreographer and the other dancers - the death of Arnie Zane and of another dancer of the Company, Handsome Damien Acquavella, to whom Jones tenderly called D-Man -, and performed frequently from then on by very different dancers. Bill T. Jones answered evoking exactly the need to reconstruct the emotions that had been experienced so that the dancers could have access to the meaning of the piece:

"In 14 years this piece must have been performed by around 100 different dancers. So whenever new dancers dance it I have to make them go back to the time when the piece was created: when Arnie had just died, when the company was desolate. They have to be transported to that time. Why? So that they cry? No. So that they can understand what the challenge is. They have to understand that." 9

For Bill T. Jones, life experience is the core of art itself. In this reflexive orientation, the choreographer expresses the emotional experience lived in face of loss and disease in some of his works, especially in the years following the death of Arnie Zane - he died in 1988 from an AIDS-related disease. ${ }^{10}$ Still/Here (1994) was created in this context. A year earlier, the nostalgic solo Achilles Loved Patroclus (1993) revealed the pain of Jones. Let us focus first in this piece strongly motivated by the emotional experience of Zane's death.

The dance Achilles Loved Patroclus, created for the dancer Arthur Aviles, may be seen as a tribute to the love of two people who died prematurely. ${ }^{11}$ Achilles and Patroclus, who in the Homeric tradition were inseparable friends, seem to merge in the interpretation of Aviles, whose movement combines the ruggedness and outer projection of the vocabulary pertaining to the technique of classical dance with an expressionist tension. Achilles' pelvic movements suggest an erotic relationship with an absent body. The dancer both rises, expressing strength, and falls flat, dragging his body like a hero, resisting the pain of an announced death right up to the last moment; he succumbs, but rises up again. In the end, indignant and inconsolable, he makes a pantomime that represents the gestures of a scream - similar to Achilles' scream when his friend Patroclus dies in the battlefield. The hellenic ambience is strengthened by the

9 In an interview that Bill T. Jones gave me in November 2003, in Madrid.

10 In his autobiography, Jones reveals that they were both HIV positive (Jones and Gillespie 1995: 179). After Zane's death, Jones kept the name of the company in tribute to his collaborator and companion.

11 The first time I saw the piece Achilles Loved Patroclus was in December 1993, in Paris. 
columns that constitute the scenery and by the costumes that evoke the suits of armours worn by warriors. The battlefield is summoned by the sentences from the Iliad that describe devastation. Achilles Loved Patroclus is a dance that may be read as a symbolic depiction of Jones' experience: the friendship and love between Jones and Zane; the death of Zane; and the pain of Jones.

The following year, Jones deals with the issue of survival for people who are in the brink of life and death. Still/Here, premiered in $1994,{ }^{12}$ is not a work about death, but about a fundamental existential matter: How to live? The answer is given in a dance piece loaded with strong feelings of discouragement, but also of hope and solidarity among individuals, and in which the experiences of the people directly involved are verbally expressed. These experiences are, on a second level of representation, those of the choreographic discourse symbolized by the movement of the ten dancers.

In order to collect material for this piece, Bill T. Jones promoted, throughout around two years (between November, 1992, and April, 1994), several workshops - Survival Workshops: Talking and Moving about Life and Death, were they called -, with about eighty cancer and aids patients (children, young people and adults) that were being given hospital treatment in different US towns. The issue raised as a starting point for the workshop was: What does it mean for a person to know they have a mortal disease? The nature of the disease doesn't matter much because every survivor has to face that matter. During the workshops, Bill T. Jones asked the participants if they could express their feelings towards the disease using gestures. The sessions were video-recorded and later the dancers learned the movements recorded, memorized the name of each patient, the words pronounced, and the personal histories that were told. These elements were subsequently integrated in the performance as filmed images, choreographed movements and poems sung.

The piece lasts about two hours and is divided in two parts. The first part, Still, is a meditative dance, with original music by composer Kenneth Frazelle, played by The Lark Quartet with Bill Finizio (percussion), and the lyrics, consisting of texts gathered in the "survival workshops", are interpreted by the singer Odetta. The performance starts with all the dancers of the Bill T. Jones/Arnie Zane Dance Company on stage: they move slowly with soft controlled movements, establishing a "shy" communication among themselves both through vision and physical contact. Later on, we start to hear the voice of Odetta:

"Her eyes/ Her eyes/ I remember her eyes./ She called me into the room./ I could see it in her eyes./ Let's have it straight of, yes or no?/ I couldn't listen./ I was empty./ Wordless./ She didn't even get to shut the door [...]"

12 The first time I saw the piece Still/Here was in September 1994, in Lyon, on the occasion of its premiere, and the second time was in May 1995, in Lisbon. 
Over these poignant words, there are duets in which the bodies, quick and agitated, roll over each other or grab each other with tension; movements of sustentation, as when one of the dancers is held and projected through space by the other; movements that express contradictory feelings, as in a trio in which two of the dancers pull a third one in opposite directions; meditative solos in which the bodies reveal hesitation, as if they didn't know where to go or what to do next.

In another part of the dance, and in the sole moment in which a dancer tells a personal history, Lawrence Goldhuber dances a solo while at the same time verbally expressing his experience regarding the evolution of the illness and death of his own mother:

"[...] I remember one evening my mama started having trouble touching her nose. At the time I got to the hospital, she was being shaken by seizures. It was the first point I realized she was going to die. [...] I've seen a lot of this kind of death lately. You know, the slow, bit-by-bit kind. That is why I ride on pretending like it's normal. Because it has become normal. And let's face it. It's always the same $[\ldots]$ "

Goldhuber speaks and dances at the same time. His movement either marks the rhythm of the words or interprets them, miming their meaning, as when he says his mother had gone bald and touches his own head with both hands, gathering them below his chin, or when he mimics pretending, simulating he is walking calmly, arms dropped to his sides swinging heavy.

By the end of Still, the dancers are disposed sculpturally, forming a solid and firm pyramid.

In the second part, Here, the vigorous movements predominate. The texts allude to hope; dance enhances the expression of this sentiment. The costumes, by Liz Prince, are red (in the first part they were light-coloured). On the screens, images of giant throbbing hearts are projected - visual effects that reinforce the energetic atmosphere of this second part. A dazzling energy invades the bodies of the dancers as they make choreographic figures that express a strong solidarity among them. They hold hands and run around in a circle; they drop hands and, taking advantage of the energy that emanates from the collective running, spin around and around; again holding hands, they form straight lines and intertwine themselves, forming filigrees before building an arrow-like figure in whose tip a dancer is being held.

Dancing, once again more smoothly and contemplative, flows over the voices of participants in the workshops, recorded and processed using a sampler by the rock composer Vernon Reid: "[...] Tell me./ Tell me. Tell me how to fight./ Tell me how to fight this disease/ because I'm going to win [...]” Over these voices, there are solo dances more self-absorbed and less communicative. 
Near the end of the piece, the feeling of hope acquires an unmistakable expression. The stimulus is set off by the name of one of the participants in the workshop, Hope, and develops metaphorically through choreographic suggestions. Bill T. Jones' voice off is heard:

“[...] And Hope. There is Hope. [...] How auspicious, we have the goddess of hope here today. Did I plan it, right? All right, Hope, just lean over here... Lean a bit over David, please. Support her. Allow her to pass Hope around. Excuse me if I get to poetic today. Try again, Hope. Let the group take you around. There she goes. Don't let her fall. Don't drop Hope. OK. Good. Good."

Behind Jones' voice, we can hear the laughter of the participants that we imagine are reacting joyfully to the choreographic suggestions the choreographer keeps making. Meanwhile, on stage, a dancer is held up in the air by two other dancers, her body maintained horizontally; two more duets follow in which one of the elements holds and carries the other, alternately. In the dance of Bill T. Jones, a body that supports the other is the choreographic expression of a relationship of solidarity between people.

Still/Here is a work that builds from elements of reality, i.e., the expressions of lived experiences. These expressions are transformed in terms of sound and choreography via artistic conventions: the voices of the participants in the "survival workshops" were absorbed by Odetta's singing and the gestural descriptions of chirurgical interventions, the emotions and the feelings are poured into the abstract and symbolic forms of the choreography. No one in Still/Here is visibly ill or dying. Still/Here is a work about suffering but also about hope - it faces the side of life.

I wrote down the majority of these remarks, mostly related to choreography and symbolism of the movement, when I watched the premiere of the work in the Biennale de la Danse de Lyon, in September 1994. The work was well received and did not give rise to criticism other than that concerning artistic content, which, naturally, contextualized the piece at a time particularly marked by the tragic consequences of AIDS on the lives of people directly involved - the media, various artistic expressions (literature, cinema, theatre, performance, and also dance), associations and organizations mobilized to reflect, disclose, and report on this new reality.

After the world premiere of Still/Here in Europe at the Biennale de la Danse de Lyon, in September 1994, the Bill T. Jones/Arnie Zane Dance Company returned to the US for a tour with their new creation. But right before the performance was to be presented in the country, Bill T. Jones and the Company were surprised by a brutal text written by Arlene Croce entitled "Discussing the undiscussable", in which the North-American dance critic reinforced the 
boundaries between art and life and defended the legitimacy of refusing to see a dance performance, referring directly to Still/Here. Croce starts by announcing that she had not watched the performance and did not intend to review it because, she argued talking about the interpreters, "I can't review someone I feel sorry for or hopeless about", and, referring to Bill T. Jones himself, "I think of him as literally undiscussable - the most extreme case among the distressingly many now representing themselves to the public not as artists but as victims and martyrs" (Croce 1994: 55). Still/Here, a performance that Croce didn't even watch, was an example of what the dance critic termed "victim art".

This text set in motion a series of critical responses by essayists, dance theorists and artists. The responsibilities of the critic regarding the reactions they can arouse were discussed, as Siegel (1996) warns - Still/Here was the object of several protests and boycotts in various parts of the US -; some artists also reacted affirming categorically their freedom and refusing any attitude aimed at controlling them politically. ${ }^{13}$ And the debate on the frontiers between art and life was reignited, as Copeland (1995) points out.

Bill T. Jones did not escape unharmed from the battle between the defenders and the detractors of Still/Here and in 1996, when he was asked how he felt regarding the whole polemic, he vented out: "It is difficult to keep on making art". ${ }^{14}$ The choreographer hadn't anticipated that Still/Here might generate such polemic or that the legitimacy of approaching choreographically an experience that is common to all human beings might be questioned:

"Still/Here talks about something we all share. It is not a piece that carries rage. On the contrary. The people that had a negative reaction towards Still/Here did not understand that I was searching for something that no one could deny we all share. People are not sure yet that men and women are equal. People are not sure yet that black and white have the same intelligence. But no one can deny that our bodies have a trajectory that it is born, grows up and dies. Mortality, which makes us vulnerable beings, is what unites the human experience more than anything else." 15

If in Still/Here Jones' purpose was to deal with emotional topics - illness, mortality, pain, hope - these were, however, approached not in a cathartic manner, but choreographically, i.e., in a reflexive and compositional-represen-

13 French dance critic Marie-Christine Vernay published statements of the North-American choreographers Trisha Brown, Stephen Petronio and Lucinda Childs that strongly criticize Croce's position (Libération, April 4, 1995: 35).

14 In a press conference that Bill T. Jones held, in August 1996, in Avignon.

15 In an interview that Bill T. Jones gave me in March 1998, in London (published in Público, Artes e Ócios supplement, November 13, 1998: 4). 
tational way: reflexive because it dealt with live experience; compositional-representational because it dealt with the materials of the dance itself and the other elements of the performance - music, lyrics, costumes, sets - to develop modes of corporal signification:

"For Still/Here I created many movement frases ${ }^{16}$ and when I was doing that I wasn't crying. I was making movements phrases that I later placed in a context such as video, the environment. It was a formal experience with emotional material; an experience where I had to learn a lot. I am a choreographer. For me, topics are always a matter of the choice of movement. In Still/Here I wanted dancers to show a kind of sturdiness, such as architecture and then emotions would be like the air that circulates around the building. But the audience reads things in an extremely powerful way. Therefore I now want to get away from what is literal, what is too clear, and maybe then the audience will not feel so confronted. We'll see." ${ }^{17}$

Two years after Still/Here's premiere, Bill T. Jones seems to answer to the polemic raised by that work, whose basis was an existential and emotional topic, with Ursonate (1996), a more abstract - in the sense that it is extraneous to figurative representation - and playful choreography, built on a poem by Dadaist Kurt Schwitters, and sung by Christopher Butterfield. In this work, the games between the rhythms of the sound and the kinetic rhythms produce temporary meanings, design fugitive architectures, in permanent construction, deconstruction and reconfiguration: sometimes people come together, creating geometric patterns; sometimes they disperse in a seemingly disorganized manner. For the choreographer, creating Ursonate met a different need from the one he felt when he was creating Still/Here: "I made this work after Still/Here that dealt with an emotional topic, life and death, but now I don't feel the need to do that." 18 Ursonate, "one of the more formal ${ }^{19}$ choreographies I've ever done", ${ }^{20}$ is a playful dance piece and, in some sections, the dancers cross the

16 Dancers and choreographers often use the expression "movement phrase" to refer to sequential chaining and simultaneous coordination of multiple units of movement. Bill T. Jones precisely defines it and explains the linguistic analogy implied: "A movement phrase is a series of gestures a choreographer creates using elements of time and space. Choreographers think about movement phrases the way writers think about words and sentences. Where a series of words comprise a sentence and sentences build a paragraph, movement phrases represent the building blocks of a dance work" (Jones 2000).

17 In an interview that Bill T. Jones gave me in August 1996, in Avignon (published in Público, November 9, 1996: 30).

18 As Bill T. Jones explained in a press conference he held in August 1996, in Avignon.

19 Choreographers and dancers often use the expression "formal choreography" to refer to a choreographic style that intentionally does not underlie the expression of emotions or other elements of theatricality, as narration, construction of characters or use of meaningful gestures.

20 As Bill T. Jones explained in a press conference he held in August 1996, in Avignon. 
stage carrying inflated mattresses, banal objects that Bill T. Jones and Gregory Bain conceived evoking the class of objects that could be used in Dadaists art works. $^{21}$

Working on a poem written by Schwitters, an artist affiliated with a movement that broke the aesthetic canons and the traditional concept of the aesthetic object at the beginning of the $20^{\text {th }}$ century, Jones responded indirectly, but combatively, to the criticisms he received from the conservative sectors. Jones himself agrees with this interpretation:

"It is absolutely true. I was able to answer the world because I answered myself. In the midst of the confusion that Still/Here generated I asked myself what I should do, I wondered about what I still believed. I decided to tell myself what I was told when Arnie died: "You either keep on living with your suffering and punishment or you find what you really love and to which you can give everything you have." I love dance, I love art. So, I picked up Kurt Schwitters' work, a kind of a model for the 20th century who with his method and spirit got ahead of time. I decided to give myself to that piece and see what I could find. I found in it a protection but I also discovered a lot about myself. In that sense, you are right. I was able to answer the world, my critics, because I was able to answer myself." 22

\section{CONCLUSION: LOOKING BACK AND MOVING FORWARD}

Dancing is for Bill T. Jones a way for the choreographer to examine reality and work with his own experience. In dancing, personal experience is reconstructed and transformed through movement languages, dance techniques and methods of choreographic composition. In the processes of reconstruction and expression of experiences, symbols play an important role. Emotional expression is a dimension of the self that intervenes in the construction of the dance. In Bill T. Jones's works analyzed in this essay, the "emotional force" (Rosaldo 1984: 178) is shown in the movements of the dancers and in the relationships that they establish between themselves: solitude, the feeling of loss and sorrow are symbolized by the heavy movements, danced on the floor and downward directed at the earth; hope, trust, the feeling of mutual help and the spirit of cooperation among people are symbolized by vast movements that open out to the outside world, projected in space, when dancers

21 The first time I saw the dance piece Ursonate was in August 1996, in Avignon, and the second time was in February 1997, in Lisbon.

22 In an interview that Bill T. Jones gave me in March 1998, in London (published in Público, Artes e Ócios supplement, November 13, 1998: 4). 
get close to each other or hold hands, forming cohesive groups to receive and carry a solitary body.

In 2003, the Bill T. Jones/Arnie Zane Dance Company presented a revival of Still/Here, called The Phantom Project: Still/Here Looking On..$^{23}$ It lasts half of the time of the first version; some choreographic sections were cut and others were added; the video device has been simplified and the music was rearranged. Jones places the new version of the piece at the heart of the celebrations of the twentieth anniversary of his company, recalling, throughout the performance, some of the works created since 1973. He was not one of the performers of the piece in 1994, but he is now. He dances and speaks at the same time, enunciating the titles, dates and giving other distinguishing information about those pieces, verbally or through movement.

1994: "Then there was Still/Here. I guess a lot of people were very angry and very sad. Just like now. I know I was", says the performer, evoking that time. Then Jones remembers how it was essential to work with the participants in the Survival Workshops: Talking and Moving about Life and Death. An "amazing experience", he asserts, recalling, then, many of their names, emotions and the ways they have discovered to express themselves.

The Phantom Project: Still/Here Looking On is a piece through which the choreographer seems to look back and to analyze the conditions under which he can live in the present, with hope, strength, joy, but also facing the reality he knows by lived experience. I agree that with The Phantom Project: Still/Here Looking On Jones was also "very consciously attempting to distance himself from the confrontations of the early mid-90s" (Dent 2005: 37), a distance that, in fact, he would soon begin to create, after the discussion raised by Still/Here in 1994, as I tried to demonstrate. In this sense, the "allegories of passing" (Martin 2008) also seem to resonate here.

But a look into the past, to the emotional, artistic, social and political aspects that motivated Bill T. Jones to create Still/Here, materialized on stage in 1994, can not only help us to better understand the conditions that informed Bill T. Jones live experiences on those days and enlighten the meaning of the choreographer's movements going forward, but also to reinforce the assumption that dance is an important source of knowledge of how emotions emerge and are socially perceived in a particular context of relationships that make values, beliefs and expectations visible. 


\section{REFERENCES}

BECKER, Howard S., 1982, Art Worlds. Berkeley: University of California Press.

BENEDICT, Ruth, 1934, Patterns of Culture. London and Cambridge: Routledge.

COPELAND, Roger, 1995, “Not/There': Croce, criticism and culture wars”, Dance Theatre Journal, 12 (1): 15-18.

CROCE, Arlene, 1994, "Discussing the undiscussable", The New Yorker, 26 ${ }^{\text {th }}$ December: 54-60.

DARWIN, Charles, 1872, The Expression of the Emotions in Man and Animals. London: John Murray.

DENT, Michelle, 2005, “Checking the time: Bill T. Jones' American utopia”, The Drama Review, T186: 24-47.

FAZENDA, Maria José, 2007, Dança Teatral: Ideias, Experiências, Acções. Oeiras: Celta.

FOSTER, Susan Leigh, 1986, Reading Dancing: Bodies and Subjects in Contemporary American

Dance. Berkeley: University of California Press.

FOSTER, Susan Leigh, 1996, "Introduction", in Susan L. Foster (ed.), Corporealities: Dancing

Knowledge, Culture and Power. London and New York: Routledge, xi-xvii.

FRAZER, James G., 1890, The Golden Bough. New York: Macmillan.

GEERTZ, Clifford, 1973, "Deep play: notes on the Balinese cockfight", in Clifford Geertz,

The Interpretation of Cultures: Selected Essays. New York: Basic Books, 412-453.

GELL, Alfred, 1998, Art and Agency: Anthropological Theory. Oxford: Oxford University Press. GRAHAM, Martha, 1991, Blood Memory. New York: Washington Square Press.

HASKELL, Arnold L., 1960, The Wonderful World of Dance. London: Macdonald.

HOGAN, Patrick Colm, 201 1, What Literature Teaches Us about Emotion. Cambridge and London: Cambridge University Press.

JONES, Bill T., 2000, "The road to a premiere: from Italy to Iowa”, Bill T Jones/Arnie Zane Dance Company News, 1 (1).

JONES, Bill T., 2013, Je suis une histoire: Abécédaire spirituel. Paris: Actes Sud.

JONES, Bill T., Johanna BOYCE, Ann DALY, and Carol MARTIN, 1988, "Movement and gender: a roundtable discussion", The Drama Review, 32 (4): 82-101.

JONES, Bill T., and Peggy GILlESPIE, 1995, Last Night on Earth. New York: Pantheon Books.

JOWITT, Deborah, 1994 [1983], "Expression and expressionism in American modern dance", in Janet Adshead-Lansdale and June Layson (eds.), Dance History: An Introduction. London: Routledge, 169-181.

LANGER, Susanne K., 1988, Mind: An Essay on Human Feeling. Baltimore and London: The Johns Hopkins University Press.

LUTZ, Catherine A., 1998, Unnatural Emotions: Everyday Sentiments on a Micronesian Atoll and

Their Challenge to Western Theory. Chicago and London: The University of Chicago Press.

LUTZ, Catherine A., and Geoffrey M. WHITE, 1986, "The anthropology of emotions", Annual Review of Anthropology, 15: 405-436.

MARTIN, Randy, 2008, "Allegories of passing in Bill T. Jones", Dance Research Journal, 40 (2): 74-87.

MORRIS, Gay, 2001, "What he called himself: issues of identity in early dances by Bill T. Jones", in Jane C. Desmond (ed.), Dancing Desires: Choreographing Sexualities on and off the Stage. Madison: The University of Wisconsin Press, 243-263. 
MURPHY, Jacqueline Shea, 2007, The People Have Never Stopped Dancing: Native American Modern Dance Histories. Minneapolis: University of Minnesota Press.

NETTL, Paul, 1966, Histoire de la danse et de la musique de ballet. Paris: Payot.

NOVACK, Cynthia J., 1990, Sharing the Dance: Contact Improvisation and American Culture. Madison: University of Wisconsin Press.

NOVACK, Cynthia J., 1993, "Processes of perception in three dancing bodies", Antropologia Portuguesa, 11: 77-89.

NOVERRE, Jean Georges, 1760, Lettres sur la danse et sur les ballets. Lyon: Chez Aimé de la Roche.

PORTE, Alain, 1992, François Delsarte, une anthologie. Paris: Editions IPMC.

ROSALDO, Renato I., 1984, "Grief and a headhunter's rage: on the cultural force of emotions", in Edward M. Bruner (ed.), Text, Play and Story: The Construction and Reconstruction of Self and Society. Washington, DC: American Ethnological Society, 178-195.

SACHS, Curt, 1937, World History of the Dance. Translated by Bessie Schönberg. New York: W. W. Norton \& Company.

SCHIEFFELIN, Edward, 1976, The Sorrow of the Lonely and the Burning of the Dancers. New York: St. Martin's Press.

SIEGEL, Marcia B., 1996, "Virtual criticism and the dance of death", The Drama Review, 40 (2): 60-70.

SORRELL, Walter, 1967, The Dance through the Ages. London: Thames and Hudson.

SPENCER, Herbert, 1968 [1857], “The origin and function of music”, Essays: Scientific, Political, and Speculative, vol. I. London: Williams and Norgate, 210-238.

THOMPSON, Robert Farris, 1974, African Art in Motion. Los Angeles: University of California Press.

TURNER, Victor, 1987, The Anthropology of Performance. New York: PAJ Publications.

TYLOR, Edward B., 1881, "Arts of pleasure", in Edward B. Tylor, Anthropology: An Introduction of the Study of Man and Civilization. London: Macmillan, 287-308. 